Bulletin UASMV serie Agriculture 70(2)/2013, 447-448

Print ISSN 1843-5246; Electronic ISSN 1843-5386

\title{
Estimations of Flood Waste from Rural Dumpsites Located on Floodplains from Neamț County, Romania
}

\author{
Florin -Constantin MIHAI*
}

Faculty of Geography and Geology „Alexandru Ioan Cuza” University, Carol I Avenue No.20A, RO-700505, Iaşi, Romania; mihai.florin86@yahoo.com

\begin{abstract}
Waste dumping is a serious environmental threat to major rivers from extra- Carpathian Region of Neamț county in the proximity of villages because the lack of waste collection services. In this context, floodplains are frequently susceptible to such bad practices, these areas being also exposed to stronger floods. The paper aims to calculate the potential waste taken from these areas in order to assess a quantitative impact of these bad practices.
\end{abstract}

Keywords: dumpsite, floodplain, rural waste, floods, quantitative assessments,

Introduction Dumpsites are frequently located on floodplains of major rivers in the proximity of built-up areas. These susceptible areas from extra- Carpathian region of Neamt county are most exposed to illegal dumping (Mihai et al., 2013). In this context, the paper outlines the role played by floods on this environmental issue for the main catchments.

Aims and objectives. The paper proposes a quantitative assessment method of flood waste generated from uncontrolled waste disposed on floodplains from extra-Carpathian region of Neamt county.

Material and MEthod. The proposed method completes and follows others quantitative assessments methods of illegal dumping (Mihai, 2012, 2013, Mihai et al., 2012) which estimates the household waste disposed by communes and villages into surroundings. $\mathrm{Q}_{\mathrm{df}}$ and $\mathrm{Q}_{\mathrm{wr}}$ indicators (calculated at the village scale in the previous studies) are essential in calculating the amounts of flood waste $\left(\mathrm{Q}_{\mathrm{fw}}\right)$ according to the relation:

$\mathbf{Q}_{\mathrm{fw}}=\mathbf{Q}_{\mathbf{w r} \text { tot }} * \mathbf{A}_{\mathbf{P}}$ or $\mathbf{Q}_{\mathrm{fw}}=\mathbf{Q}_{\mathrm{df} \text { tot }} * \mathbf{A}_{\mathbf{P}}, \mathbf{Q}_{\mathrm{fw} \text { tot }}$ - amounts of waste taken over by floods from several localities $\left(\mathrm{Q}_{\mathrm{wr} 1}+. .+\mathrm{Q}_{\mathrm{wr} n+1}\right), \mathrm{A}_{\mathrm{P}}$ - the accumulation (storage) period of the waste, expressed in number of days (frequently the period between two floods, especially in the extra-Carpathian sector). This period varies according to geographical region analyzed due to a specific climatic and hydrological context and values of $\mathrm{Q}_{\mathrm{wr}} \& \mathrm{Q}_{\mathrm{df}}$ must be expressed în $\mathrm{t} /$ day or $\mathrm{kg} /$ day. $\mathrm{Q}_{\mathrm{wr} \text { tot }}$ - total waste disposed by selected localities along a riverbed or/ creek bank (in the proximity of built-up area ), $\mathrm{Q}_{\mathrm{df}}$ tot - total waste disposed (by selected localities) in the alluvial plain of a river in the Subcarpathian sector (Ozana /Cracău /Bistri $\square$ a) and corridor valley (Moldova / Siret)

Determination of PET amounts uncontrolled disposed is achieved by following relation: $\mathbf{Q}_{\mathrm{fwPET}}=\mathbf{Q}_{\mathbf{w r} / \mathrm{day}} * \mathbf{S p}(\mathbf{\%}) * \mathbf{A}_{\mathbf{p}}, \mathrm{Sp}-$ share of plastics (\%) in waste composition, information taken from the average composition of municipal waste of Neam $\square$ County, measured through BALKWASTE Life - Project (2010). The accumulation period of waste is set for floodplains of major rivers from study area (Moldova, Siret, Bistri $\square \mathrm{a}$, Ozana, Cracău) according to strong floods which were frequently in the past decade such as 2005 (July), 2008 (July 22 to 31 ) and 2010 (June 18 to 27).

In this context, the acumulation periods taken into account for this analysis are: January 1, 2003 - June 30th 2005 (546 days) and July 1, 2008 - June 18, 2010 ( 352 days). 
Results and Discussions. Estimated amounts of flood waste from such disposal sites (located on floodplains ) are significant for all rivers in 2003-2005, about $4000 \mathrm{t}$ in 546 days including 60 tons of PET accordin to table 1. In both periods, Bistri $\square$ a and Siret valleys generated the most of flood waste from study area. Strong floods from last decade often cleaned the wastes dumped in floodplains which amplified the destructive effects in downstream. Some of this waste is accumulating behind dams or hydropower plants or are scattered on surrounding lands, particularly floatable fractions like wood (agricultural source) or PET bottles (domestic \& commercial sources).

The progress on the expansion of waste collection services in rural territory was insignificant between 2003-2008, however, there has been an upward trend since the closure of old dumpites in 2009, according to EU acquis.

Tab. 1

Estimations of flood waste generated following natural hazards in 2005 and 2010 on rivers from sub-Carpathian area and corridor valley sector

\begin{tabular}{|c|c|c|c|c|}
\hline Rivers & $\begin{array}{c}\mathrm{Q}_{\mathrm{df}_{-}} \\
(\mathrm{t} / 546 \text { days) }\end{array}$ & $\begin{array}{c}\mathrm{Q}_{\mathrm{fw}} \text { PET } \\
(\mathrm{t} / 546 \text { day) }\end{array}$ & $\begin{array}{c}\mathrm{Q}_{\mathrm{fw}}-\mathrm{C}_{\mathrm{f}} \\
(\mathrm{t} / 352 \text { days })\end{array}$ & $\begin{array}{c}\mathrm{Q}_{\mathrm{fw}} \text { PET } \\
(\mathrm{t} / 352 \text { days })\end{array}$ \\
\hline Moldova (total) & 637.3579 & 41.428 & 410.8974 & 46.02 \\
\hline Siret (total) & 708.72 & 46.066 & 456.903 & 51.17 \\
\hline $\begin{array}{c}\text { Ozana (\& } \\
\text { Nem } \square \text { isor })\end{array}$ & 562.56 & 36.566 & 362.676 & 40.619 \\
\hline Cracău (total) & 600.5817 & 39.037 & 387.188 & 43.365 \\
\hline Bistri $\square \mathrm{a}$ & 1485.044 & 96.527 & 957.3915 & 107.227 \\
\hline Total & 3994.2636 & 259.624 & 2575.0559 & 288.401 \\
\hline
\end{tabular}

Conclusion Strong floods from Moldova, Bistri $\square$ a and Siret catchments often cleaned the wastes dumped in floodplains which amplified the destructive effects in downstream. Despite these issues, just these floods favored this convenient and inadequate practice of local residents as well as in the mountainous region. The paper performs for the first time a quantitative analysis of flood waste generated by these local dumpsites.

\section{REFERENCES}

1. Mihai, F.C. (2013). Quantitative assessment of household waste disposed in floodplains of rivers from extra-Carpathian region of Neam $\square$ county, Romania. $13^{\text {th }}$ International Multidisciplinary Scientific GeoConference on Ecology, Economics, Education And Legislation, SGEM 2013, Conference Proceedings, vol. 1:781-788

2. Mihai, F.C., A. Ursu, P. Ichim and D.A, Chelaru (2013). Determining rural areas vulnerable to illegal dumping using GIS techniques. Case study: Neam $\square$ County, Romania. $13^{\text {th }}$ International Multidisciplinary Scientific GeoConference on Ecology, Economics, Education And Legislation, SGEM 2013, Conference Proceedings vol.1 : 275-282

3. Mihai, F.C, L. Apostol, A. Ursu and P. Ichim (2012). Vulnerability of mountain rivers to waste dumping from Neamț County, Romania. Geographia Napocensis 6 (2):51-59

4. Mihai, F.C. (2012). Improper Household Waste Disposal in Rural Territory. Case Study: Neam $\square$ County, Romania. Bulletin USAMV Agriculture 69 (2): 15-20.

5. $\quad * * *$,Balkwaste- Life Project (2010) Final report on municipal solid waste composition in Romania and Bulgaria (http://www.balkwaste.eu/?lang=ro) 